Pakistan Journal of Humanities and Social Sciences
Volume 8, Number 1, 2020, Pages $\mathbf{1}-\mathbf{9}$

\title{
Nigeria's Self-Sufficiency in Rice and Wheat: An Evaluation of Growth Enhancement Support Scheme and Anchor Borrower Program
}

\author{
Ibrahim Iliyasu $^{1}$, Saifullahi Lawal ${ }^{2}$ \\ ${ }^{1}$ Department of Economics, Umaru Musa Yar'adua University, Katsina, Email: Ibrahim.iliyasu@umyu.edu.ng \\ ${ }^{2}$ School of Management, Katsina State Institute of Technology and Management
}

\section{ARTICLE INFO}

\begin{tabular}{lr}
\hline Article History: & \\
Received: $\quad$ December 20, 2019 \\
Revised: $\quad$ March 01, 2020 \\
Accepted: $\quad$ March 15, 2020 \\
Available Online:
\end{tabular}

\author{
Keywords: \\ Agricultural Policy \\ Self-sufficiency \\ Rice \\ Wheat
}

\section{JEL Classification Codes:} Q11, Q18

\section{A B S T R A C T}

This paper revisits one of Nigeria's paradox: net food importer (especially in rice and wheat) accompanied by huge import bill running into billions of Naira despite huge agricultural potentials of 82 million hectares of arable land, the conducive agro-ecology system for varieties of crops, and dynamics smallholder farmers; Growth Enhancement Support Scheme (GESS, 2011) and Anchor Borrower Programs $(A B P, 2015)$ are among various initiatives aimed at boosting domestic production capacity particularly of rice and wheat; reduced importation and import bills and consequently conserve scarce foreign exchange. Base on the before-and-after approach of evaluating policies and programs, a regression approach to single factor Analysis of Variance (ANOVA) was used to determine whether a significant mean difference exists on area harvested, domestic production, and import of rice and wheat in Nigeria before (1988-2009) and after (2010-2019) the implementation of the two programs. The findings indicate a significant and moderate increase in Nigeria's capacity to produce more rice and wheat respectively; and the programs have not drastically reduced rice and wheat importation in Nigeria. The paper recommends the expansion and sustainability of the programs with an emphasis on wheat, quality output, and competitive price if Nigeria is serious about achieving selfsufficiency in rice and wheat. Creative Common Attribution Non-Commercial 4.0

Corresponding Author's Email: ibrahim.iliyasu@umyu.edu.ng

\section{Introduction}

From the era of the oil boom in the 1970s to the present, Nigeria's agriculture is characterized by persistent excess demand over domestic food production and supply, especially of rice and wheat. This situation was earlier recognized by Kwanashi et al. (1997) who pointed out that due to high population growth rate, stagnant or declining growth in agricultural output, high rate of urbanization, rising per capita income stimulated by the oil export boom and change in the pattern of food consumption in terms of quantitative and qualitative adaptations to new food preferences and consumption habits (rice, wheat, and wheat-based consumer-foods) there exist excess demand oversupply of food in Nigeria. Also recently the Agricultural Promotion Policy 2016-2020 re-emphasized the point by acknowledging that Nigeria is facing two key gaps in agriculture today: an inability to meet domestic food requirements and an inability to export at quality levels required for market success.

Two alternative options are open for Nigeria to address the situation: Firstly, to rely on food importation to complement domestic production and supply. Over the years various governments have tried this option. However, it can best be described as the easiest, short term, and unsustainable solution to the problems because it entirely depends on the availability of foreign exchange to pay for the huge food import bill and experienced have shown that Nigeria's struggle to pay for its import bill whenever crude oil price plummets or 
when militants in the oil-producing states disrupted production ${ }^{1}$. The second option is to boost domestic production, which is a long-run solution to the problem and requires a concerted effort to reduce or eliminate constraints to domestic production faced by farmers especially the smallholder farmers who produced about 99 percent of total crop output (Sab et al., 2017). However, in the past, Nigeria attempts to boost domestic agricultural production through various policies; programs and intervention have not always been successful due to frequent changes in government agricultural policies (Onwuka, 2017). A renewed commitment to transformed Nigeria's agriculture started in 2011 through the implementation of a new strategy: the Agricultural Transformation Agenda (ATA, 2011-2015). To continue and consolidate on the gain recorded from (ATA, 2011-2015); the Agricultural Promotion Policy (APP, 2016-2020) came in to being. Two specific programs associated with the above respective policies are the Growth Enhancement Support Scheme (GESS, 2011) and Anchor Borrower Program (ABP, 2015).

The (GESS, 2011) has a broad objective of supporting resources constrained farmers by providing various incentives required to improve their productivity. While, its specific objectives are: to provide support directly to 5 million farmers each year for 4 years to enable them to procure agricultural inputs at affordable prices, at the right time and place; to increase the productivity of farmers across the length and breadth of the country through increased use of fertilizer i.e. $50 \mathrm{~kg} / \mathrm{ha}$ from $13 \mathrm{~kg} / \mathrm{ha}$ and to change the role of Government from direct procurement and distribution of fertilizer to a facilitator of procurement, the regulator of fertilizer quality and catalyst of active private sector participation in the fertilizer value chain (Federal Ministry of Agriculture and Rural Development [FMARD], 2011). While the ABP (2015) broad objectives are to create economic linkage between smallholder farmers and reputable large-scale processors to increase agricultural output and significantly improving capacity utilization of processors. While it's specific objectives include: to increase banks' financing to the agricultural sector; reduce agricultural commodity importation and conserve external reserves; to increase capacity utilization of agricultural firms; to create a new generation of farmers/entrepreneurs and employment; to deepen the cashless policy and financial inclusion; to reduce the level of poverty among smallholder farmers; to assist rural smallholder farmers to grow from subsistence to commercial production levels (Central Bank of Nigeria [CBN], 2016).

A careful look at these programs revealed that they are targeted at reducing or eliminating key constraints hindering Nigerian farmers to boost or improve their products such as timely access to quality and affordable inputs (fertilizer, improved seeds, and pesticides) and adequate and affordable finances. Thus, the broad objective of this paper is to investigate the extent to which these programs help boost Nigeria's domestic food production capacity and supply particularly of rice and wheat. While the specific objectives are to:

- Investigate the effect of the programs on land area cultivated for rice and wheat

- Investigate the effect of the programs on rice and wheat output

- Investigate the effect of the programs on Nigeria's rice and wheat importation

The paper is organized as follows: section one is the introduction; section two established the context and the literature review; section three outline the methodology; section four reports results and findings; and finally section five conclude and outline policy recommendations.

\section{Literature Review}

This section provides a brief contextual and theoretical foundation to the study through the overview of agricultural policies, conceptual clarification, and empirical literature review.

\subsection{Economic Policy and Nigeria Agriculture, 2000- 2019}

Although the Nigerian agricultural sector has suffered from years of mismanagement, inconsistent and poorly conceived policies, leaf services, lack of basic infrastructure; it remains the largest single sector of the economy, providing employment for a large segment of the

\footnotetext{
${ }^{1}$ In a bid to reduce forex exchange demand pressure and promote domestic production, on July $1^{\text {st }} 2015$ the central bank of Nigeria prohibit forex access to rice importers and other 40 items.
} 
workforce and constituting the mainstay of Nigeria's largely rural population. Also, the sector has shown persistent resilience in terms of its contribution to the country's real Gross Domestic Product (GDP) and its average real growth rate as suggested by the information in table 1 and table 2 below respectively.

Table 1: Sectoral average Share of Real GDP 2000-2019

\begin{tabular}{ccccc}
\hline SECTORS & $\mathbf{2 0 0 0 - 2 0 0 4}$ & $\mathbf{2 0 0 5 - 2 0 0 9}$ & $\mathbf{2 0 1 0 - 2 0 1 4}$ & $\mathbf{2 0 1 5 - 2 0 1 9}$ \\
\hline Agriculture & 22.7 & 24.99 & 23.45 & 24.59 \\
Industry & 37.56 & 27.47 & 21.46 & 22.48 \\
Service & 39.74 & 47.54 & 55.06 & 52.93 \\
\hline Total GDP & $\mathbf{1 0 0 . 0 0}$ & $\mathbf{1 0 0 . 0 0}$ & $\mathbf{1 0 0 . 0 0}$ & $\mathbf{1 0 0 . 0 0}$ \\
\hline
\end{tabular}

Source: author(s) computation from NBS GDP reports for various years

The table above shows the five years average contribution of three key sectors of agriculture, industry, and service to Nigeria's real GDP within the period under review. Agriculture recorded a lower share in 2000-2004 and 20005-2009 averaging at about 22.7 and 24.99 respectively. However, in 2010-2014 and 2015-2019 the sector contribution is ahead of industry averaging at about 23.45 and 24.59 respectively. This is an indication of the fact that the sector consistently contributes more than 20 percent of Nigeria's real GDP for the period 2000-2019. On the other hand, a closer examination of five years averages sectorial real growth rate in table 2 proved that agriculture is ahead of industry throughout the 2000- 2019 periods. Though it's average real growth rate continues to decline, it remains positive and even higher than that of services and the overall growth rate of the economy during the recessionary period of 2015-2019 this is a demonstration of the sector resilience.

Table 2: Sectoral Average Real Growth Rate 2000- 2019

\begin{tabular}{ccccc}
\hline SECTORS & $\mathbf{2 0 0 0 - 2 0 0 4}$ & $\mathbf{2 0 0 5 - 2 0 0 9}$ & $\mathbf{2 0 1 0 - 2 0 1 4}$ & $\mathbf{2 0 1 5 - 2 0 1 9}$ \\
\hline Agriculture & 15.112 & 6.766 & 4.532 & 3.15 \\
Industry & 5.52 & $(1.504)$ & 3.698 & $(0.94)$ \\
Service & 8.812 & 12.21 & 7.756 & 1.42 \\
\hline Real GDP & $\mathbf{8 . 6}$ & $\mathbf{6 . 8}$ & $\mathbf{6 . 1}$ & $\mathbf{1 . 2 6}$ \\
\hline
\end{tabular}

Source: author(s) computation from NBS statistical bulletin for various years

The key policies documents that have a direct and indirect bearing on agricultural development in Nigeria over the period 2000- 2019 include the new Nigerian Agricultural Policy 20001; the National Economic Empowerment and Development Strategies NEEDS, 2004; the Seven Points Agenda 2007; the Agricultural Transformation Agenda 2011; and currently the Agricultural Promotion Policy APP, 2016. All these policies initiative recognized the importance of agriculture in government diversification drive, creation of employment, and poverty reduction, this is because the sector is highly labor-intensive and the existence of huge, untapped potentials in terms of 82 million hectares of arable land, the conducive agro-ecology system for varieties of crops and dynamics smallholder farmers. The overall goals of Nigeria's agricultural policies revolved around import substitution, export promotion, and food selfsufficiency (Idachaba, 2006).

To achieve the overall agricultural policies objectives key programs implemented within the period under review include The Presidential Initiatives on commodities, National Special Food Security program (NSPFS), Commerce 44, Export Expansion Grant (EEG), Agricultural Credit Guarantee Scheme (ACGS), National FADAMA Development Program, National Cocoa Development Program, Commodity Development, and Marketing Companies, Nigeria Incentive-Based Risk Sharing for Agricultural Lending (NIRSAL) and lastly, Gross Enhancement Support Scheme GESS and Anchor Borrower Programs which this paper seeks to evaluate because of the continuation and consolidation of the former program by the later.

\subsection{Defining and Measuring Food Self-Sufficiency}

The Food Agricultural Organisation FAO (1999) defines food self-sufficiency as the extent to which a country can satisfy its food needs from its domestic production. This definition is subject to different interpretations by different individuals by not specifying whether a country that pursues food self-sufficiency agenda still engages in food trade with other countries. 
Clapp (2017) suggest two distinct interpretation of the above definition, firstly, food self-sufficiency mean a country eschewing all food trade and relying 100 percent on domestic production to meets its food needs. This is, however, a narrow view of the concept and a rare and difficult situation to achieve as no country can do without food importation of any sort. The second view sees food self-sufficiency to mean a country's domestic food production is equal to or exceeds 100 percent of its food consumption. This broad view does not rule out trade and the emphasis is on the country's domestic food production capacity concerning domestic food consumption. Thus, under this definition, self-sufficient countries may still pursue a degree of agricultural specialization to trade these foods with other countries.

In line with the later views, an appropriate definition of food self-sufficiency for Nigeria is a sustained substantial increase in Nigeria's capacity to produce high-quality food at competitive prices that are accompanied by a significant decrease in food importation. Two indicators are widely used to measure food self-sufficiency: (i) country's Dietary Energy Production (DEP) per capita. Under this measure, countries that produce $2500 \mathrm{kcal}$ (kcal) or more per person per day are typically considered to be self-sufficient, as consumption of at least this many calories per day is seen by most nutritionists to be necessary to ensure an adequate diet (Porkka et al., 2013). An analysis by Porkka et al. (2013) classified food production between 2000 and $2500 \mathrm{kcal}$ per person per day as "insufficient", and production below $2000 \mathrm{kcal}$ per day as "low". (ii) Self-Sufficiency Ratio (SSR), expresses food production as a ratio of available supply, as depicted by the following equation (FAO, 2012):

$$
\mathrm{SSR}=\text { Production } * 100 /(\text { Production }+ \text { Imports }- \text { Exports })
$$

FAO recommends caution in applying the SSR concept to the overall food situation of a country, because it may mask instances where a country produces one food commodity in abundance while needing to rely on imports for other food commodities (FAO, 2012). Thus, SSR is typically calculated for a specific commodity or class of commodities such as rice, wheat, maize, or cereals to give an approximation of country food self-sufficiency for a particular food in question.

Following the above exposition, the operational definitions for Nigeria's self-sufficiency in Rice and Wheat is defined as the extent to which the country level of production is close or equal to its domestic demand for the commodity and the subsequent decline in the quantity of the commodity imported into the country. For simplicity, land areas harvested, domestic production, and importation are used as parameters for measuring self-sufficiency.

\subsection{Empirical Literature Review}

This section contains literature reviewed on food security, food self-sufficiency, assessment of the Growth Enhancement Support Scheme, and Anchor Borrower Programs. Olayide et al. (2011) analyzed agricultural trade and food self-sufficiency in the context of policy development scenarios including, the Millennium Development Goals (MDGs) and democratic governance paradigms. Data used for the analyses spanned from 1970 to 2007. Descriptive statistics and trend analyses were employed to examine agricultural trade variables. Statistical inferences were drawn from the comparative analysis of the policy development scenarios. Agricultural imports for the study period witnessed an increasing trend. There was an agricultural trade imbalance as Nigeria remained a net importing nation. In all development policy scenarios, there were significant $(p<0.01)$ increases in total imports, total exports, and net imports. Overall, national food self-insufficiency averaged 29.35 ( \pm 4.08) percent.

Adegbola et al. (2011) investigate food security situations, government intervention, and the place of effective storage in Nigeria; using secondary sources of information they found that lack of adequate post-harvest practices as the chief bane for food security in Nigeria and suggested that more should be done to see that food are adequately store after they are produced to reduce wastage and improve food security. Astou (2015) analyzed the impact of food import dependency on poverty in Nigeria and Senegal using several correlation analyses between the level of food imports and the level of poverty; he found that in Senegal, there was a significant non-lagged relationship, suggesting that food is being imported to address poverty, there were no significant correlations for Nigeria or a lagged relationship in either 
country. He then concludes that food imports do not cause poverty but that they also do not contribute to alleviating it.

Udoma et al. (2016) studied the prospects of achieving rice self-sufficiency through irrigation in Nigeria. After reviewing the existing literature they found that the prospects are hampered by underdeveloped sub-sector promoted by fragmented, inconsistent, and unimplemented policies; multiple water regulatory institutions with the overlapping and duplicating mandate; poor management system, and high cost of inputs. They conclude that for Nigeria to achieve rice self-sufficiency through irrigation there is a need to amend policies on irrigation and water resources, create a conducive market for local producers and provide subsidies on appropriate farm inputs and implements.

Tiri et al. (2014) assess Gross Enhancement Support Scheme Program visa viz food security situation in Nigeria; they argued that GESS is an innovative approach to fertilizer subsidy and other inputs administration through an electronic system that ensures only registered farmers benefit through the engagement of private sector in the delivery and distribution of fertilizer and other inputs directly to the farmers. They conclude that the success of the program will ensure food security in Nigeria. Ahmed et al. (2016) assess the effectiveness of the Gross Enhancement Support Scheme of food security status of rural farming households in Adamawa State, Nigeria. Data were collected using questionnaires and interviews and analyzed using descriptive statistics and food security index. They found that 62.5 percent of respondents are food secured, despite reporting insufficient seed and fertilizer and poor GSM network for proper operation of e-wallet.

Odoemelam and Maduka (2016) studied the participation of Abia State farmers in the Gross Enhancement Support Scheme. Using multiple regressions they found a significant relationship between farmers' participation and their socioeconomic characteristics and the programs was fairly effective in inputs delivery to the farmers as well as brought some positive changes in farmers' crop performance despite the challenges of delay in the arrival of inputs and non-specified fertilizer type. Michael et al. (2018) evaluate the implementation of the Gross Enhancement Support Scheme in Nigeria using systematic literature reviewed and secondary data from government sources on the scheme. Findings indicated that the Scheme was able to deliver subsidized agricultural inputs to small-scale farmers with relative ease and at an affordable rate which was able to boost farm output. However, the scheme was affected majorly by its politicization, the inability of the governments to release funds to agro-dealers leading to late delivery of inputs, and the lack of support service (extension) to farmers.

Grace and Lawrence (2017) evaluate the prospects of the Anchor Borrower Program for small scale farmers in Nigeria. They reviewed the performance of the pilot project in Kebbi State, Nigeria, and found that about 78,000 farmers benefited from the program who recorded a yield of 7.5-8 tons per hectare as against the previous 2.0 tons per hectare. Obih and Baiyegunhi (2018) studied field experiences of Small Holder Farmers (SHFs), banks, and rice millers who participated in the ABP program for the 2016/2017 farming season. The study observed that $A B P$ has the potentials to facilitate Nigeria's quest for food security. However, the key challenges found to be threatening the success and sustainability of ABP included delays in timely disbursement of funds by deposit money banks (DMBs), inadequate personnel and institutional framework, side-selling of harvested paddy rice by SHFs, State government undue involvement in the $\mathrm{ABP}$, and poor rural infrastructures.

Okeke et al. (2019) examine the effect of the Anchor Borrowers' Programme (ABP) on rice farmers in Benue State, Nigeria. Using independent t-test and Endogenous Switching Regression Model (ESRM) to analyses data collected with the aid of structured questionnaires from 768 rice farmers consisting of 388 beneficiaries and 380 non-beneficiaries from 18 communities. The results showed that the income and farm output of beneficiaries of Anchor Borrowers' Programme was significantly higher compared to the non-beneficiaries; that rice farmers' access to ABP was significantly influenced by their socioeconomic characteristics and that beneficiary and non-beneficiary rice farmers were not better or worse in terms of farm income than a random rice farmer from the samples. Umeh and Adejo (2019) assess the effects of the Anchor Borrowers' Programme (ABP) on rice farmers in Kebbi State, Nigeria. Primary data collected through questionnaire from 226 rice farmers ( 113 beneficiaries and 113 non-beneficiaries of $A B P$ ) and annual time series data on Nigeria's rice import quantity and 
cost (1990-2016) are analyses with the help of descriptive and inferential statistics. The result indicates trend fluctuations in the quantity and cost of Nigeria's rice import. Beneficiaries recorded 0.98 mean technical efficiency compared to the non-beneficiaries with only 0.81 mean technical efficiency; this translated to higher mean output $(5504.4 \mathrm{~kg} / \mathrm{ha})$ of beneficiaries, compared to the mean output of $3267.7 \mathrm{~kg} / \mathrm{ha}$ of non-beneficiaries.

Two key points are drawn from the literature reviewed. Firstly, the literature on food self-sufficiency established that Nigeria is not a food self-sufficient country. Secondly, evidence on the performance of the Gross Enhancement Support Scheme and Anchor Borrower Program can best be described as preliminary with emphasis on the potentials of the programs to achieved the desired objectives if well implemented. Based on this, this paper seeks to consolidate the existing evidence with more robust and scientific techniques for evaluating the two programs.

\section{Methodology}

This section outline the sources of data used for the study describes the variables and explained the techniques of investigation.

\subsection{Sources of Data and Description of the Variables}

To evaluate the cumulative effects of the Gross Enhancement Support Scheme (GESS) and Anchor Borrower Program (ABP) on Nigeria self-sufficiency on rice and wheat, data on area harvested expressed in thousands of hectares, domestic production, and importation expressed in thousands of tons for rice and wheat are collected from Food and Agricultural Organisation (FAO) country stat and index Mundi over the period (1988 -2019). Also, a policy dummy variable was created by the researchers designated as zero to represent the period (1988-2009) before the start of the two programs and one representing the period (20102019) after the implementation of the two programs.

\subsection{Techniques of Investigation}

Base on the before-and-after approach of evaluating policies and programs, a regression approach to single factor Analysis of Variance (ANOVA) was used to determine whether a significant mean difference exists on area harvested, domestic production, and import of rice and wheat in Nigeria before (1988-2009) and after (2010-2019) the implementation of the two programs. The general model used to estimates means differences parameters for all the variables are specified as follows:

$$
Y_{t}=\emptyset_{0}+\emptyset_{1} D_{t}+\varepsilon_{t}
$$

Where: $Y_{t}=$ is either land areas harvested, domestic productions and or importation, $D_{t}$ $=$ is the policy dummy variable, $\emptyset_{0}$ and $\emptyset_{1}=$ are the two parameters to be estimated with $\emptyset_{0}$ representing the average value of the variables before the implementations of the programs and $\emptyset_{1}$ representing the average increase or decrease in the variables after the implementation of the programs. $\varepsilon_{t}=$ is the white noise error terms that account for other factors that might cause changes in the variable under consideration. A priori we expect to have a significant positive mean difference in area harvested and domestic production for rice and wheat (i.e. $\emptyset_{1}$ should have a positive sign), implying that the programs have significantly improved Nigeria's capacity to produce more rice and wheat domestically and a significant negative means difference for the importation of rice and wheat (i.e. $\emptyset_{1}$ should have a negative sign), implying that, Nigeria's have significantly reduced the importation of rice and wheat since the start of the programs.

\section{Results and Discussion}

This section presents a trend analysis of the study variables as well as the summary of the findings from the regression approach to single factor Analysis of Variance (ANOVA).

\subsection{Trend Analysis for Rice and Wheat Self-sufficiency in Nigeria}

Figure 1 above depicts the behaviors of land areas harvested, domestic production, and importation of rice within the study periods. Generally, four key episodes are identified as follows: all the variables have trended upward over the years; they tend to have steeper slopes during the implementation of the two programs; rice importation have trended 
downward from its highest peak of about 3 million tons around 2011, and domestic rice production recorded highest output of about 7 million tons in 2016 . The last two points are a pointer to the possibility of desired impacts as a result of the implementation of the two programs.

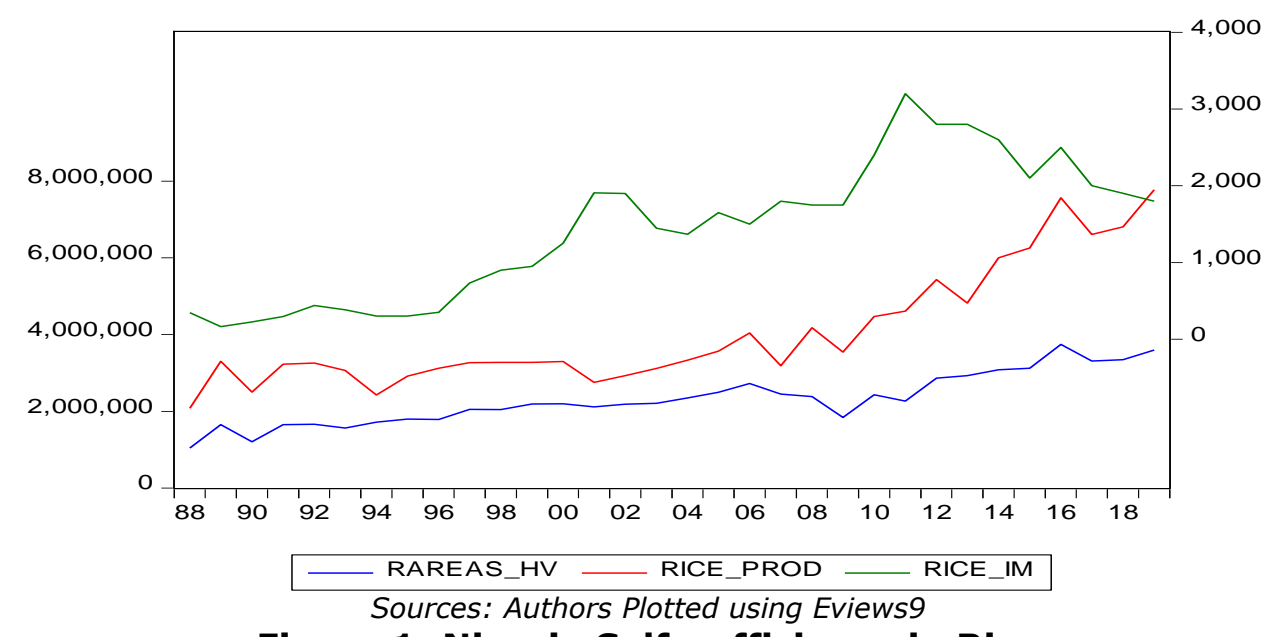

Figure 1: Nigeria Self-sufficiency in Rice

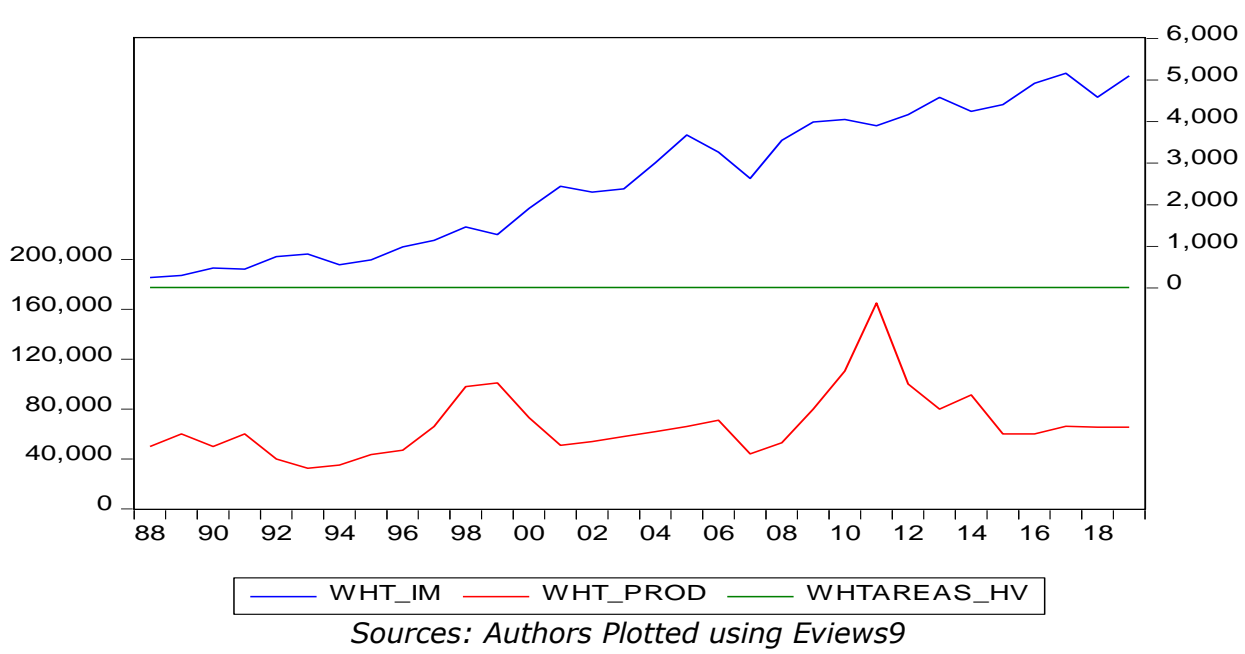

Figure 2: Nigeria Self-sufficiency in Wheat

On the one hand, figure 2 shows the trend of areas harvested, domestic production, and importation of wheat in Nigeria. Both domestic production and importation have fluctuated more often; production recorded its highest peak of about 1.6 million tons around 2011 while importation doesn't seem to decline even after the implementation of the programs.

\subsection{Nigeria's Self-sufficiency in Rice}

In line with our working definition of self-sufficiency, table 3 below indicated that there is a positive and statistically significant means difference in all three parameters. Land areas harvested or utilized in rice production on average increase by about $1,101,614$ million hectares after the implementation of the two programs from 2010-2019, compared to the average land areas utilized in rice production before the implementation of the programs 19882009; consequently the output or quantity of paddy rice produced in the country increase by an average of about $2,869,033$ million tons.

Table 3: Summary Statistics for Rice

\begin{tabular}{cccc}
\hline Variables & $\begin{array}{c}\text { Differences in } \\
\text { Means }\end{array}$ & T-Statistics & P-Value \\
\hline Areas Harvested & 1101614 & 6.649413 & 0.0000 \\
Production & 2869033 & 9.897787 & 0.0000 \\
Importation & 1423.591 & 6.239324 & 0.0000 \\
\hline
\end{tabular}

Sources: Authors Summary from Eviews 9 Output 
Also, the quantity of milled rice imported into Nigeria increase marginally by about 1,423 thousand tons. These results imply that the implementation of the Gross Enhancement Support Scheme (GESS) and Anchor Borrower Programs (ABP) by the federal government has reduced significant constraints face by farmers and increase Nigeria's level of rice selfsufficiency through committing more land to production and consequent increase in output. In terms of importation the paper argues that even though we failed to get negative differences, the marginal positive differences could have been larger without the implementation of the two programs.

\subsection{Nigeria Self-sufficiency in Wheat}

In terms of wheat self-sufficiency, the results in table 4 revealed that all three parameters have a statistically significant positive, but small magnitude means differences compare to rice parameters. Land areas harvested or utilized for wheat production increase by an average of only about 698.51 thousand hectares.

Table 4: Summary Statistics for Wheat

\begin{tabular}{cccc}
\hline Variables & $\begin{array}{c}\text { Differences in } \\
\text { Means }\end{array}$ & T-Statistics & P-Value \\
\hline Areas Harvested & 0.69851 & 4.444748 & 0.0001 \\
Production & 27493.98 & 3.084945 & 0.0043 \\
Importation & 2769.718 & 6.930022 & 0.0000 \\
\hline
\end{tabular}

Sources: Authors Summary from Eviews 9 Output

Consequently, the output or quantity of wheat produced in the country increase by an average of about 27,493.98 tons for the period 2010-2019. The quantity of wheat imported also increase marginally by about $2,769.718$ the paper argues this could have been larger if the two programs were not implemented. Overall, the paper argues that Gross Enhancement Support Scheme (GESS) and Anchor Borrower Programs (ABP) have to increase Nigeria's productive capacity in rice significantly and moderately in wheat through the change in land areas allocated by farmers in the production of the two commodities as well as consequent increase their output. However, the programs did not drastically reduce the quantity of rice and wheat imported in the country. The paper findings corroborate the existing evidence for instances, Michael et al. (2018) have reported positive effects of the Gross Enhancement Support Scheme of farmers' output. While, (Grace \& Lawrences 2017; Okeke et al., 2019; Umeh \& Adejo 2019) have also found positive effects of Anchor Borrowers Programs on farmer's output.

\section{Conclusion and Recommendation}

The study evaluates whether Gross Enhancement Support Scheme and Anchor Borrower Programs have significantly increased the level of Nigeria's self-sufficiency in rice and wheat; base on the before-and-after approach of evaluating policies and programs. The results indicate that Nigeria's capacity to produce rice increase significantly but moderately in wheat; and that the programs have not drastically reduced rice and wheat importation in Nigeria. Based on the study findings the following recommendations were offered:

- Beyond the improvement of domestic rice and wheat production capacity, the quality and price should be competitive with foreign products to achieve drastic import reduction.

- The programs should be sustained with special emphasis on wheat production for improved domestic production capacity.

\section{References}

Adegbola J. A., Bamishaiye E. I., and Daura A. M. (2011). Food security in Nigeria: Government's Intervention and the place of effective storage. Asian Journal of Agriculture and Rural Development, 1(2), 56-63.

Ahmed, F.F., Yusuf, A.B., \& Dunah, F. (2016). Effect of Growth Enhancement Support Scheme on Food Security Status of Rural Farming Households in Adamawa State, Nigeria. EPRA International Journal of Economic and Business Review. 4(5)

Astou, D. (2015). Food Imports as a Hindrance to Food Security and Sustainable development: The Cases of Nigeria and Senegal". CUNY Academic Works. 
CBN (2016). Anchor Borrowers' Programme Guidelines. Abuja, Nigeria.

Clapp, J. (20017). Food self-sufficiency: Making sense of it, and when it makes sense. Food Policy Journal. Available at: https://www.researchgate.net/publication/311977359

Food and Agricultural Organisation of the United Nations (2020). FAOSTAT statistical database. [Rome]: FAO.www.fao.org/faostat/en/\#home

Food and Agricultural Organisation of the United Nations (1999). Implications of Economic Policy for Food Security: A Training Manual. [Rome]: FAO.

Food and Agricultural Organisation of the United Nations(2012). FAO Statistical Yearbook 2012 World Food and Agriculture. [Rome]: FAO.

Federal Ministry of Agriculture and Rural Development FMARD (2011). Growth Enhancement Support Scheme (GESS). Abuja, Nigeria.

Federal Ministry of Agriculture and Rural Development FMARD (2013). Agricultural Transformation Agenda Support Program - Phase 1 (ATASP-1). Abuja, Nigeria

Federal Ministry of Agriculture and Rural Development FMARD (2016). The Agriculture Promotion Policy (2016 - 2020). Abuja, Nigeria.

Grace, O. E., \& Lawrence, U. O. (2017). Evaluating the Prospects of the Anchor Borrowers' Program for Small Scale Farmers in Nigeria. 21st International Farm Management Congress, John McIntyre Conference Centre, Edinburgh, Scotland, United Kingdom. Available online at www.ifmaonline.org

Idachaba, F.S. (2006). Good Intentions are not Enough: Collected Essays on Government and Nigerian Agriculture. Volume 1. The agricultural policy process. University Press Plc, Ibadan, Nigeria.

IndexMundi (2020). Data on Rice and Wheat. Retrieved froms www.indexmundi.com

Kwanashie, M., Garba, A., \& Ajilima, I. (1997). Policy Modelling in Agriculture: Testing the Response of Agriculture to Adjustment Policies in Nigeria. AERC Research Paper 57, Nairobi, Kenya.

National Bureau of Statistics NBS (2020). Annual GDP Report for Various Years. Abuja, Nigeria.

Obih, U., \& Baiyegunhi, L. (2018). Financing Smallholder Rice Farmers: A Field-Based Evidence Review of Anchor Borrowers Programme (ABP) Model in Nigeria. Journal of Economics and Behavioral Studies, 10(6(J), 229-239. https://doi.org/10.22610/jebs.v10i6(J).2613

Odoemelam L. E. \& Maduka O. A (2016). Participation of Farmers towards Growth Enhancement Support Scheme and its Effect on Crop Performance in Abia State, Nigeria. International Journal of Trend in Research and Development, 3(4).

Okeke, A.M., Mbanasor, J.A. \& Nto, P.O. (2009). Effect of Anchor Borrowers' Programme Access among Rice Farmers in Benue State, Nigeria: Application of Endogenous Switching Regression Model. International Journal of Agriculture and Earth Science, 5(3).www.iiardpub.org

Olayide, O.E., A.E. Ikpi, V.O. Okoruwa and V.O. Akinyosoye (2011). Agricultural Trade Balance and Food Self-Sufficiency: Implications for Sustainable Development in Nigeria. World Rural Observations, 3(4), 59-64. http://www.sciencepub.net/rural.

Onwuka, SI.O. (2017). Reversing Nigeria's Food Import Dependency - Agricultural Transformation. Agricultural Development, 2(1): 1-12.

Porkka, M., Kummu, M., Siebert, S., Varis, O., (2013). From Food In-sufficiency Towards Trade Dependency: A Historical Analysis of Global Food Availability. PLOS ONE 8 (12), 82714 (12pp).

Sabo, B.B., Isah, S.D., Chamo, A.M., and Rabiu, M.A (2017). Role of Smallholder Farmers in Nigeria's Food Security. Scholarly Journal of Agricultural Science, 7(1), 1-5.

Tiri, G. D. Ojoko, E. A. \& Aruwayo, A. (2014). Growth Enhancement Support Scheme (GESS) and the Challenges of Food Security in Nigeria: A Review. ARPN Journal of Agricultural and Biological Science. 9 (7). www.arpnjournals.com

Uduma, B.U., Samson, O.A., \& Mure, U.A (2016). Irrigation Potentials and Rice Self-sufficiency in Nigeria: A Review. African Journal of Agricultural Research, 11(5), 298-309

Umeh, J. C \& Adejo, M. A (2019, September 23-26). Assessment of central bank of Nigeria's anchor borrowers' program effects on rice farmers in Kebbi State, Nigeria. Invited paper presented at the 6th African Conference of Agricultural Economists, Abuja, Nigeria. 